\title{
A Meta-Analysis and an Evaluation of Trends in Obesity Prevalence among Children and Adolescents in Turkey: 1990 through 2015
}

\author{
(1) Züleyha Alper ${ }^{1}$, (1) ilker Ercan², (1) Yeşim Uncu ${ }^{1}$ \\ ${ }^{1}$ Uludağ University Faculity of Medicine, Department of Family Practice, Bursa, Turkey \\ ${ }^{2}$ Uludağ University Faculity of Medicine, Department of Biostatistics, Bursa, Turkey
}

\begin{abstract}
What is already known on this topic?
Obesity in childhood and adolescence is one of the most serious public health problems due to a remarkable increase in prevalence in recent years and its close relationship with non-communicable diseases, such as diabetes and hypertension, resulting in increased adult morbidity and mortality.
\end{abstract}

\section{What this study adds?}

The results of this present study reveal that further national, population-based surveys on the prevalence of obesity in children and adolescents are definitely needed in Turkey.

\begin{abstract}
Objective: Obesity in childhood and adolescence is one of the most serious public health problems due to a remarkable increase in prevalence in recent years and its close relationship with non-communicable diseases, such as diabetes and hypertension, resulting in increased adult morbidity and mortality. This study aims to quantify the secular trend in different regions of Turkey from 1990 to 2015 by performing a meta-analysis of childhood and adolescent obesity prevalence studies conducted.

Methods: Uludag University Library Database was searched for relevant articles published prior to March 2017. The heterogeneity of the studies in the meta-analysis was tested by the I 2 statistic and Cochran's Q test. The obesity trend analyses were examined by chi-square trend analysis with respect to five year periods. The statistical significance level was taken as $\alpha=0.05$.

Results: A total of 76 papers were initially identified addressing childhood and adolescent obesity in Turkey. Fifty-eight papers were selected for analysis. The prevalence of obesity increased from $0.6 \%$ to $7.3 \%$ with an 11.6 -fold increase between the periods 1990 - 1995 to 2011-2015. The prevalence of obesity increased in both genders. However, boys were more likely to be obese than girls.

Conclusion: Studies on obesity prevalence in the 5-19 age group in Turkey have gained importance, especially in the 2000s. While a remarkable number of prevalence studies, mostly regional, have been conducted between 2005-2011, a gradual decline was observed thereafter. Further national and population-based surveys on prevalence of obesity in children and adolescents are definitely needed in Turkey.
\end{abstract}

Keywords: Childhood, adolescence, obesity

\section{Introduction}

Obesity in childhood and adolescence generally manifests itself in school years. Even when it does not continue into adulthood, it is correlated with increased adult morbidity and mortality by causing chronic disease states such as diabetes and hypertension (1). The prevalence of obesity has been increasing rapidly and because of these facts it is now one of the most serious public health problems for the $21^{\text {st }}$ century. The World Health Organization (WHO) has reported that the percentage of overweight children under five years increased from $5 \%$ in 2000 to $6 \%$ in 2010. This increase has been estimated to result in over 42 million $(6.3 \%)$ of children being overweight in 2013. This problem 
currently affects many low and middle-income countries, and especially urban residential areas (2). The increasing trend of being overweight is a worldwide problem as the number of adults with a body mass index (BMI) of $>25$ $\mathrm{kg} / \mathrm{m}^{2}$ increased from $29.8 \%$ to $36.9 \%$ in men and from $29.8 \%$ to $38.0 \%$ in women between the years 1980 and 2013 (3).

This is also true in Turkey where rapid changes in lifestyles, including dietary and physical activity habits have contributed to a remarkable increase in the prevalence of obesity which is now accepted as a serious threat to public health. Turkish studies have reported different results for the prevalence of obesity in children and adolescents, depending upon geographic and cultural differences. According to the latest national representative data, the obesity prevalence in the 6-18 age group is $8.2 \%$ overall. The difference between genders and for area of residence are $7.3 \%$ for girls, $9.1 \%$ for boys and $9.7 \%$ in urban, $4.5 \%$ in rural settings respectively (4). Adoption of a Western lifestyle amongst children and living in an urban setting in a developing country are considered probable risk factors $(4,5)$.

Prevalence Studies of Diabetes, Hypertension, Obesity and Endocrine Diseases in Turkey data have confirmed the scale of the public health problem associated with childhood obesity. Notably, the results show that as the education level of women rises, the obesity risk decreases independent of other factors, a finding which emphasizes the importance of the education of girls in improving community health status (6).

The primary aim of this study is to identify the secular trend in the prevalence of childhood and adolescent obesity by performing a meta-analysis of studies conducted in different regions of the country between 1990 and 2015. We also aim to review the prevalence and changing trends of obesity among Turkish school children aged 5-19 years.

\section{Methods}

\section{Search Strategy}

The Uludağ University Library Database was searched to identify relevant papers in Turkish and in English published prior to March 2017 (7). The following key words were used: ['incidence' OR 'frequency' OR 'prevalence' OR 'epidemiology'] AND ['obesity' OR 'body mass index' OR 'BMI' OR 'weight gain'] AND ['Turkey' OR 'Turkish'] AND ['childhood' OR 'children' OR 'adolescence' OR 'adolescents' OR 'youth' OR 'teen' OR 'teenager'] for obesity in Turkish children and adolescents.
Studies were selected according to the following criteria:

i) A sample that included school children (5-19 years of age),

ii) Cross-sectional design,

iii) Original studies on prevalence of obesity,

iv) Studies conducted within the borders of Turkey,

v) Studies that defined obesity categories according to BMI calculated by dividing body weight ( $\mathrm{kg}$ ) by the square of height $\left(\mathrm{m}^{2}\right)$ and those that used the age and sex specific BMI percentile tables by Neyzi et al (8), or those of the centers for disease control and prevention (9) or WHO (10).

Studies which lacked sufficient data, or were repetitive studies based on the same database were considered as not meeting the inclusion criteria and were excluded.

Figure 1 summarizes the flow chart for selection of studies for inclusion in this meta-analysis for obesity.

\section{Data Extraction}

On the basis of pre-defined inclusion criteria, titles and abstracts were examined for inclusion by two independent reviewers (ZA and $\mathrm{YU}$ ) and disagreements were resolved by consensus or, if necessary, by referral to a third reviewer (IE). The full text forms were evaluated for the articles with titles and/or abstracts with insufficient information. Publication year; study time, period and place; study design; representativeness of target population; sample selection; sample size; data source; data collection; description of obesity; sex; age; study objectives; criteria for obesity; and figures that allowed calculation of obesity prevalence were extracted from the studies. We assessed the quality of all included studies on the basis of the following: study design, representativeness of target population, sample selection, sample size, response rate, data source and study objectives, data collection, description of obesity, sex, and age. Studies were rated $(++)$ if all or most of checklist criteria were

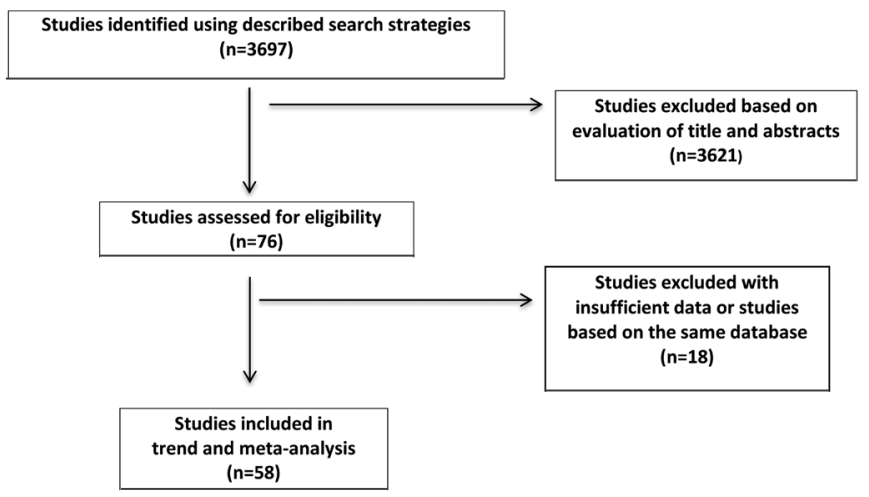

Figure 1. Flow chart for selection of studies for inclusion in this trend and meta-analysis for obesity 
fulfilled; $(+)$ if some criteria were fulfilled; and (-) if few or no criteria were fulfilled. All data extractions were ratified by one researcher (IE). Missing raw data were requested from authors by email or by phone calls.

\section{Statistical Analysis}

A meta-analysis was made for determining the summary statistics oriented towards the prevalence of obesity. The heterogeneity of the studies in the meta-analysis was tested by the $\mathrm{I}^{2}$ statistic and Cochran's $\mathrm{Q}$ test. In the heterogeneity test, $\alpha$ was taken as 0.10 . For the estimation of the summary statistics, the fixed effect model in case of homogeneity and the random effect model in the contrary case were used. The publication bias was assessed by inspection of Funnel plots. Statistics concerning the meta-analysis results are given in tables and by Forest plots.

The obesity trend analyses were examined by chi-square trend analysis with respect to 5-year periods, as there were insufficient studies conducted on a yearly basis. Thus, five blocks of 5-year periods were defined as 1990-1995, 19962000, 2001-2005, 2006-2010 and 2011-2015 and compared. In the trend analysis, instead of publication year, the year in which the field study was performed was used. For the studies in which the exact research periods were not stated, the necessary information was obtained by communicating with the author via e-mail and by phone. Any studies in which precise information was not available concerning the year the research was made were excluded from the research. By taking the 1990-1995 period as a baseline, the statistical significance levels for the next 5-year periods and the odds ratio values were calculated. The statistical significance level was taken as $\alpha=0.05$.

\section{Ethics}

Information reported in this retrospective study was collected by references to published works. Ethical responsibility is related to the authors of the studies made.

\section{Results}

The analysis included studies which were conducted in different cities and regions of Turkey on school children aged between 5-19 years. While evaluating each of the studies one by one in the meta-analysis, in the trend analysis we evaluated the total of the studies made in different regions in the same 5-year periods, instead of representing only one location, with the aim of evaluating the trends in obesity in the 5-year periods. When all of the studies done between the years 1990-1995 were used as a baseline, we observed that there was an increase in the prevalence of obesity in the following 5-year periods.
After screening 76 papers, we included 58 papers in the analysis. Figure 2 shows the Forest and Funnel plots of 58 studies of obesity prevalence with a total number of
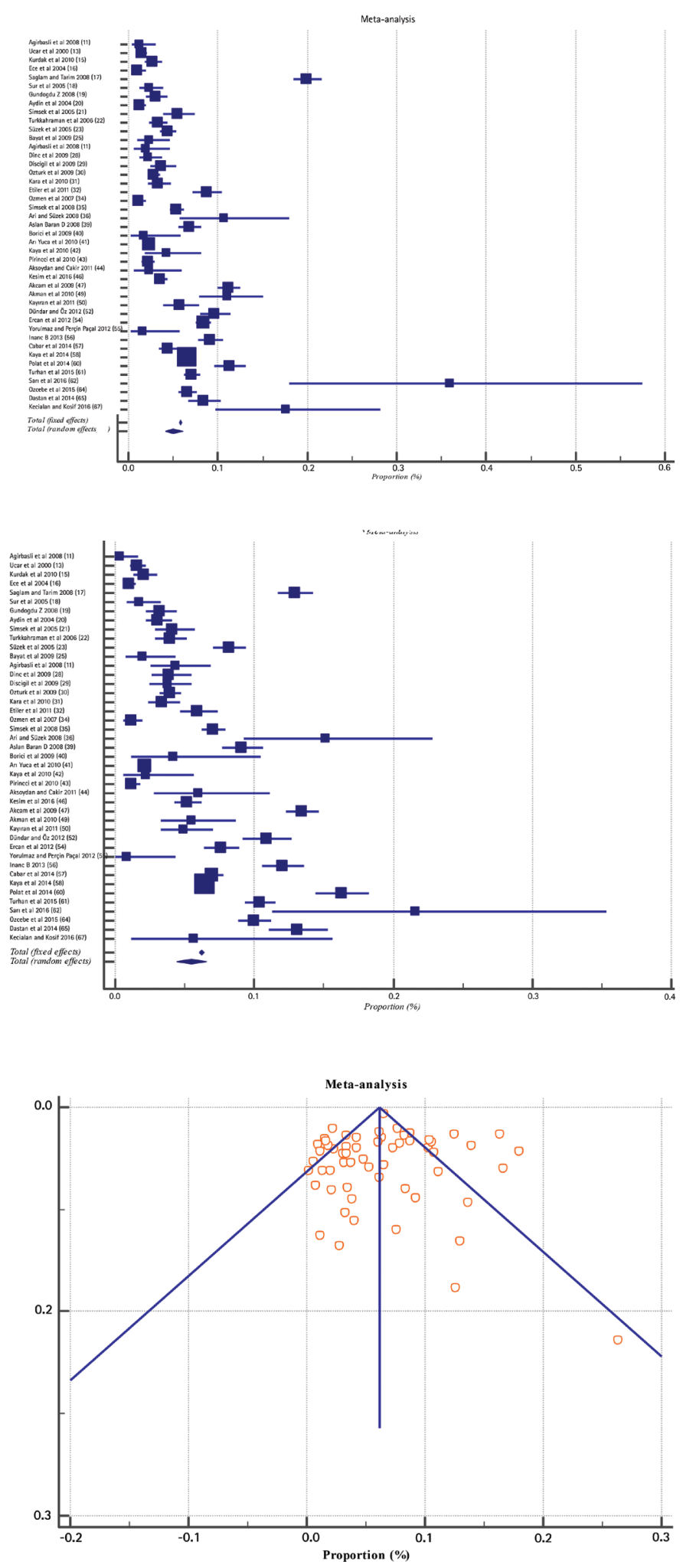

Figure 2. Pooled analysis for obesity in children and adolescents in Turkey, overall, girls and boys respectively 
subjects of 230252 Turkish school children aged 5-19 years to evaluate overall obesity prevalence. For assessing gender specific obesity prevalence 43 papers with a total of 100086 girls and 108491 boys aged 5-19 years were assessed. The prevalence of obesity was found as $5.7 \%$ [95\% confidence interval (CI), 4.8-6.6] totally, $5.0 \%$ (95\% CI, 4.1-6.1) in girls and $5.5 \%$ (95\% CI, 4.4-6.6) in boys (Table 1).

Time trend analyses based on data collection years showed that obesity increased 11.6-fold (5.8-fold for girls, 24.5-fold for boys) from 1990-1995 to 2011-2015. The prevalence of obesity increased in both genders, but boys were more likely to be obese than girls (Table 2).

While the prevalence of obesity increased from $0.7 \%$ to $7.1 \%$ between 1990-1995 and 2011-2015 (for girls: $1.2 \%$ to $6.8 \%$; for boys: $0.3 \%$ to $7.4 \%$ ) according to the data obtained from 43 publications in which the data are given separately as overall, girls and boys, we observed that the overall prevalence of obesity increased from $0.6 \%$ to $7.3 \%$ by analysing the trend with 58 publications. (Table 2,3) (Figure 3,4).

\section{Discussion}

This meta-analysis indicates that the prevalence of obesity has increased significantly among both girls and boys in Turkey since 1990 and that this increase is much more marked in boys.

In the present study, we consulted 58 different studies conducted on prevalence of obesity between 1990 and 2015 in school children aged 5-19. All studies confirmed an increase in obesity, though the magnitude of this increase varied.

\section{Study Limitations}

The meta-analysis reported here combines data across studies conducted in different cities and groups in Turkey in order to estimate trends in obesity in school children aged 5-19 with more precision than is possible in a single study. The main limitations of this meta-analysis. as with any overview. are the differences between the age groups of the study population. insufficient age-specific data and regional and cultural differences. Among these studies. there were publications whose aim was not to determine obesity prevalence and publications which did not discriminate between obesity prevalence according to gender. despite the fact that they were well designed. So. the quality of the data cannot go beyond the quality of the individual studies included and the results can only be representative of the studies that have been included and are unable to provide a representation of all studies published.

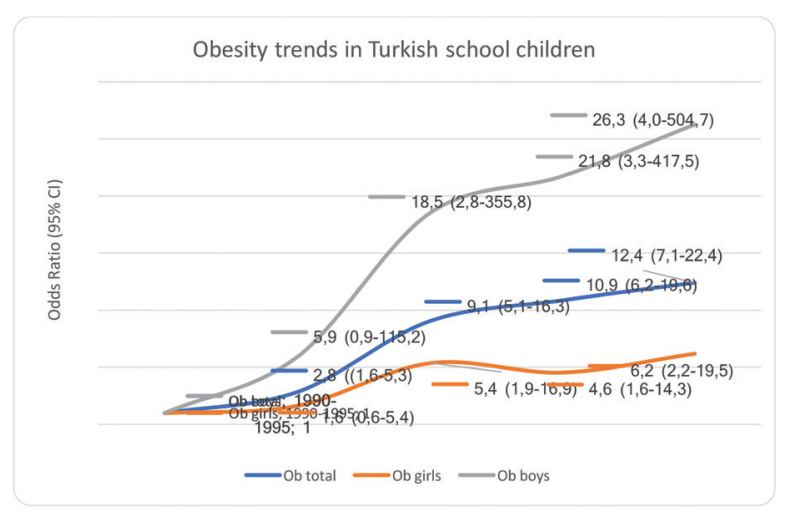

Figure 3. Trends in obesity prevalence [OR $(95 \% \mathrm{Cl})]$ in Turkish children and adolescents aged 5-19 years from 1990-1995 through 2011-2015. Data obtained from all 58 publications with and without gender discrimination

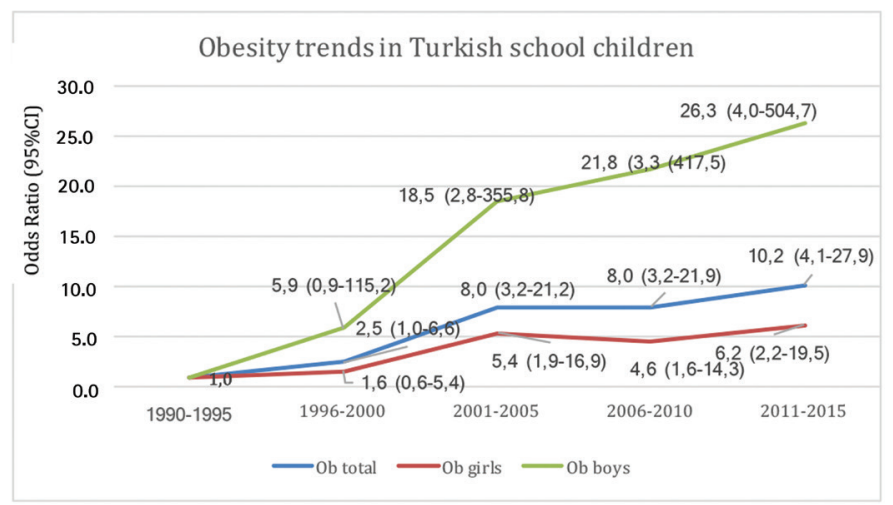

Figure 4. Trends in obesity prevalence [OR $(95 \% \mathrm{CI})]$ in Turkish children and adolescents aged 5-19 years from 19901995 through 2011-2015. Data obtained from 43 publications in which the data are given separately as overall. girls and boys

\section{Conclusion}

However, the results of this present study reveal that further national. regular population-based surveys representing Turkey on the prevalence of obesity in children and adolescents are definitely needed. We. as authors. wish to increase awareness of this global public health concern in order to develop comprehensive public health policies and strategies to improve the prevention and management of obesity and related diseases. We also wish to provide baseline data for monitoring the effectiveness of national programs for control of obesity in the future. which we suggest should be a high priority public health initiative for Turkey. It should not be forgotten that obesity. and obesityrelated non-communicable diseases. will negatively affect immediate health. quality of life and educational attainment in childhood and adolescence and will likely have a permanent negative effect on the future life of the child. 


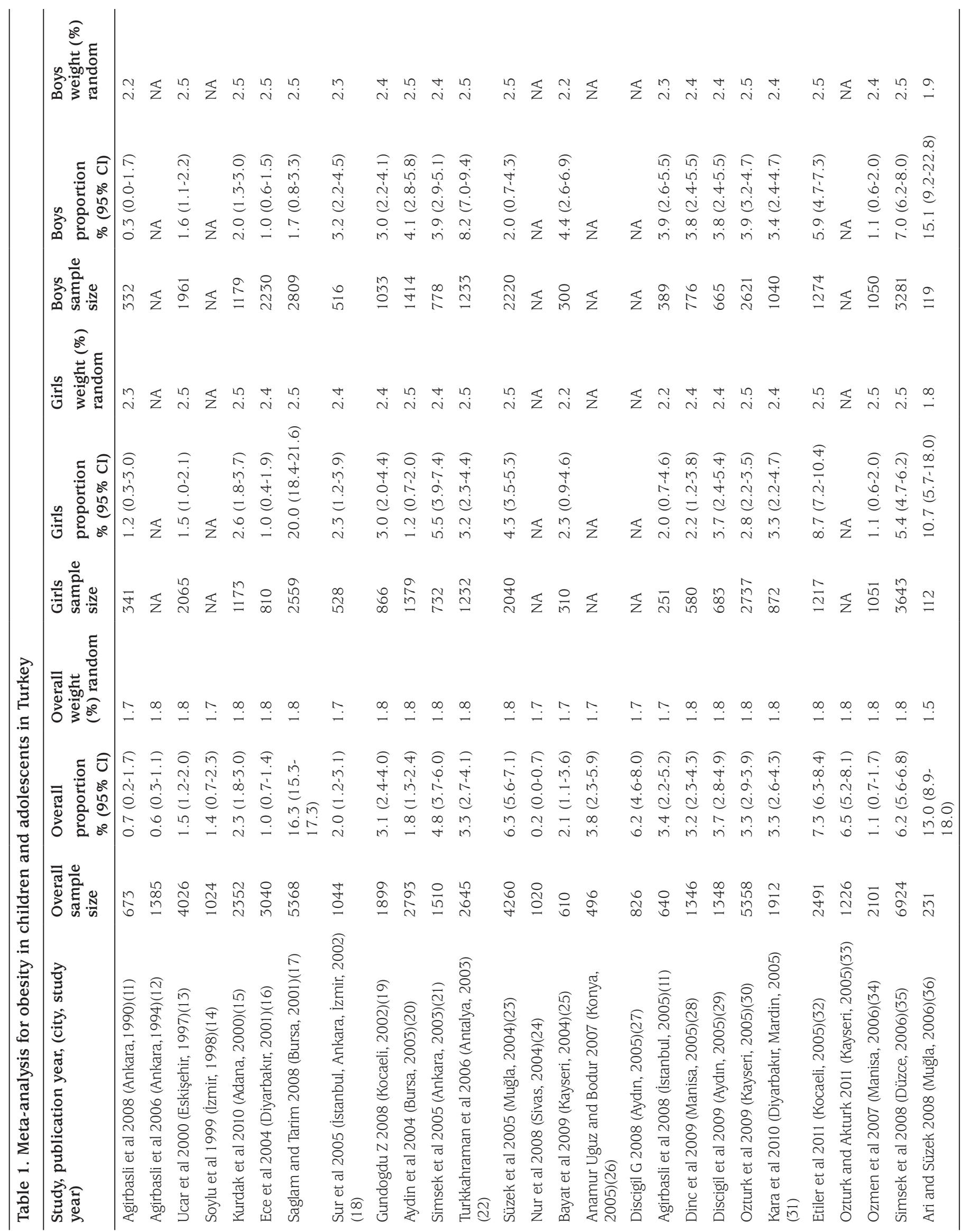




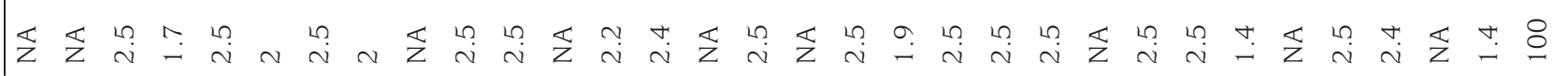

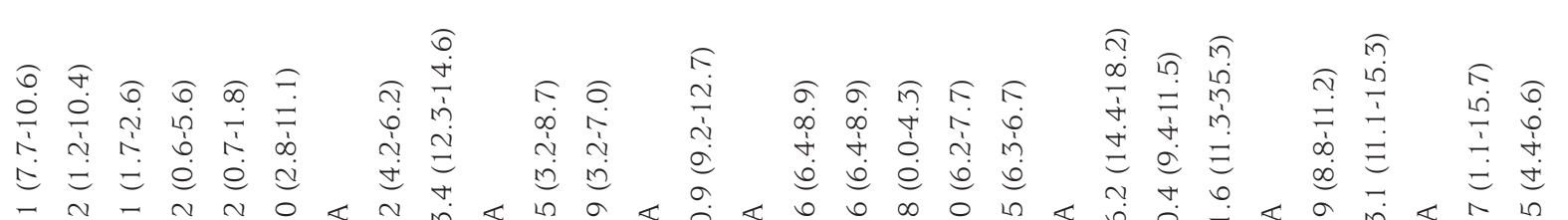

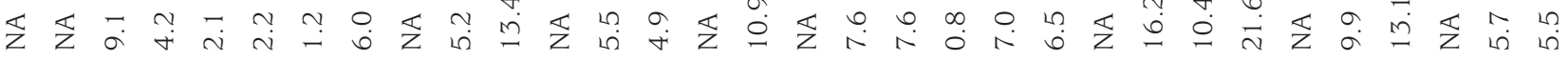

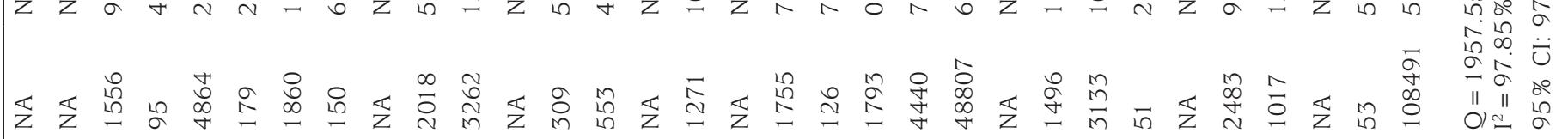

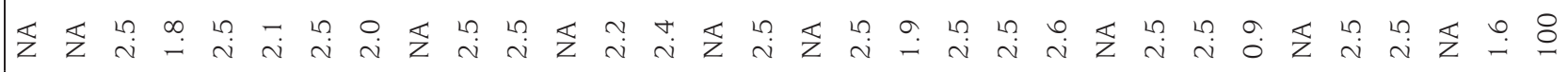

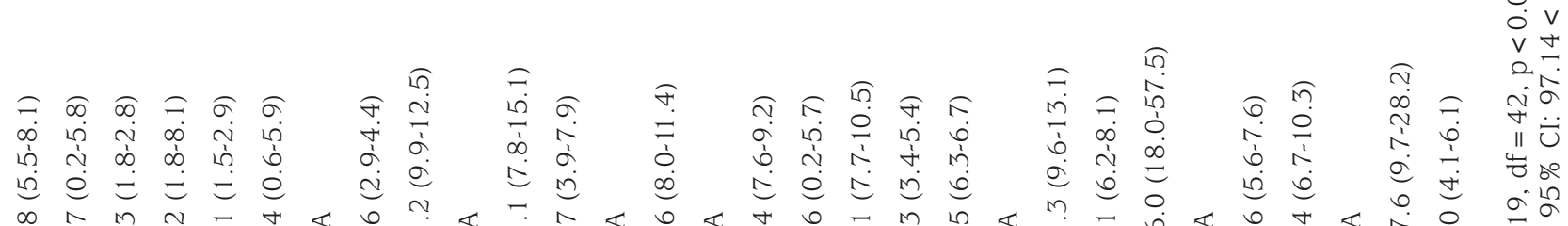

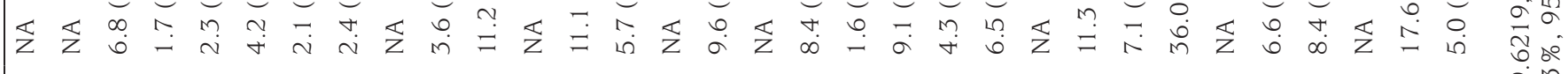

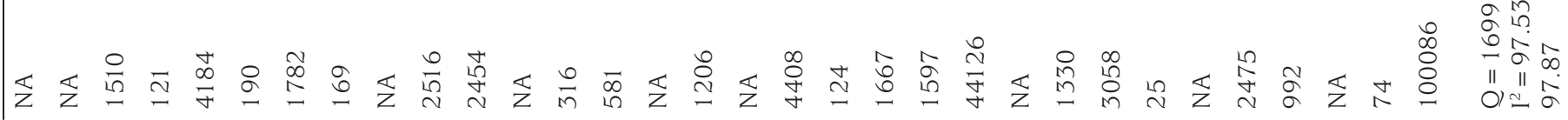

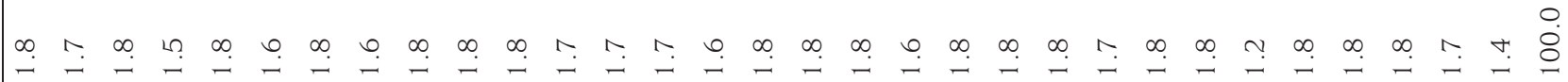

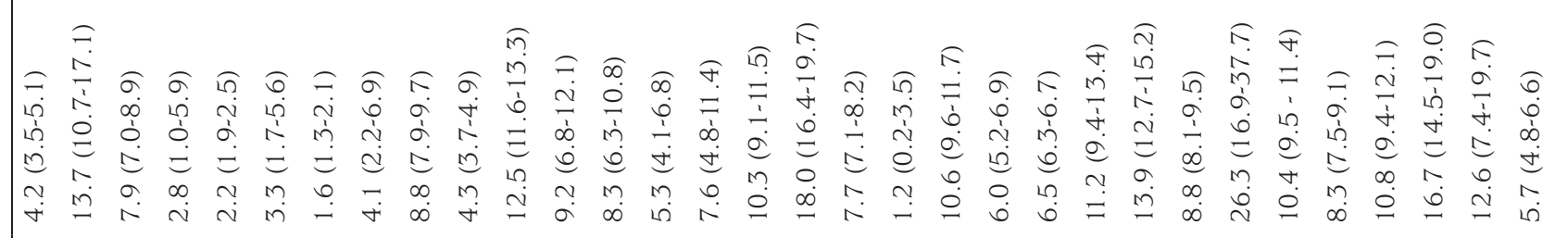

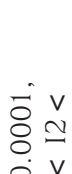

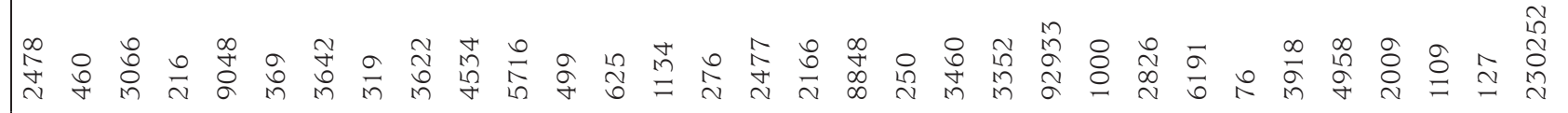

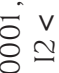
每 in 记 艺 so min จิ 50 tin 낭 $\infty$

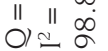

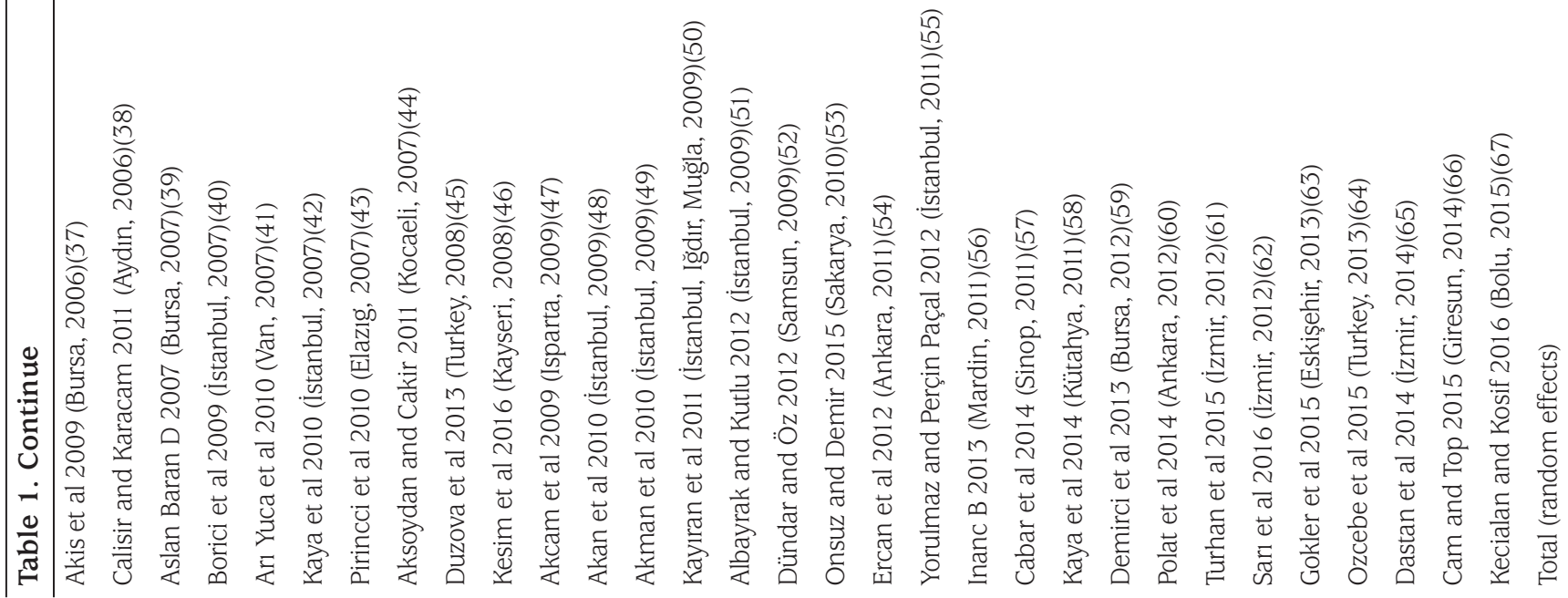




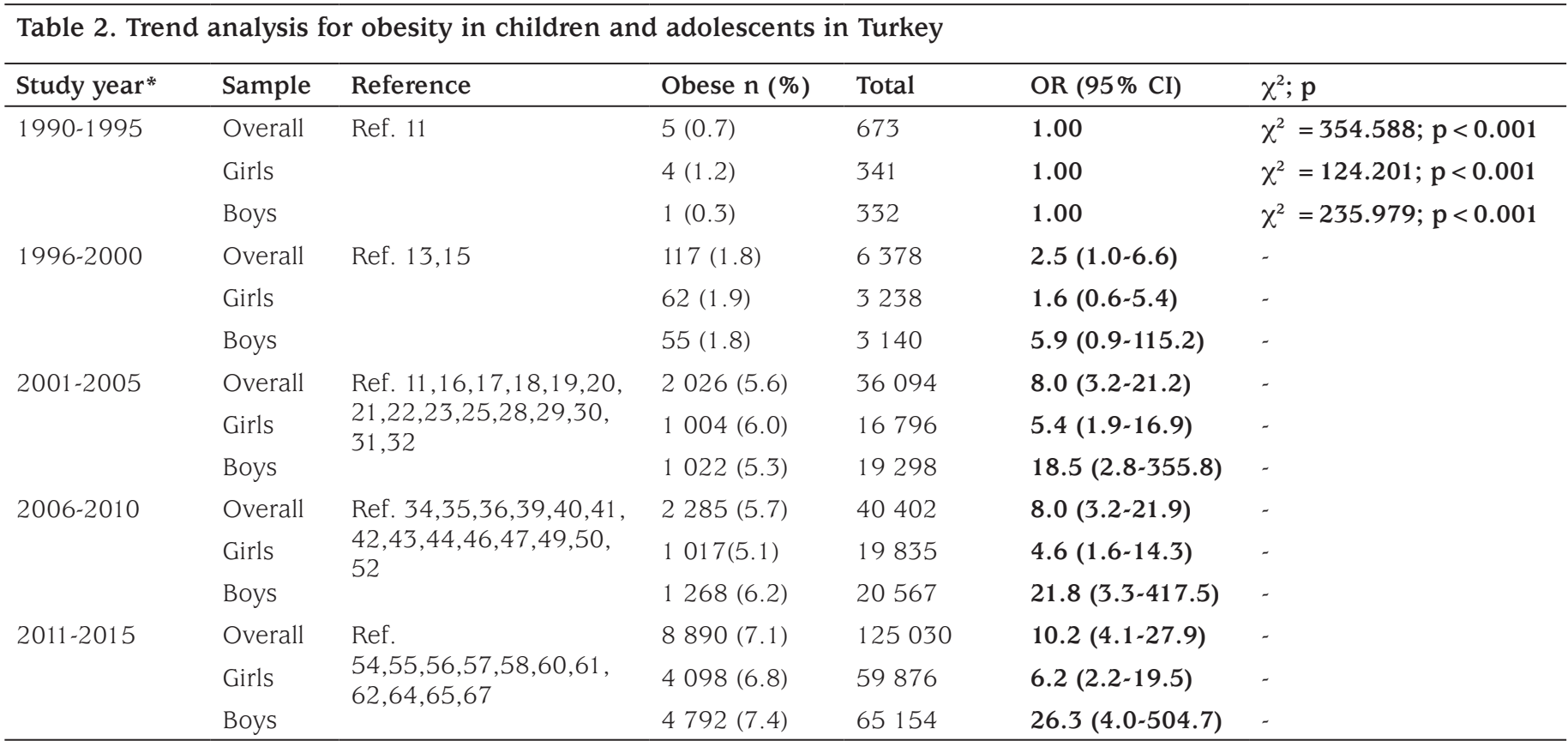

*Year during which the study was conducted

OR: odds ratio, $\mathrm{CI}$ : confidance interval

\begin{tabular}{|c|c|c|c|c|c|c|}
\hline Study year* & Sample & Reference & Obese n (\%) & Total & OR $(95 \% \mathrm{CI})$ & $\chi^{2} ; p$ \\
\hline 1990-1995 & Overall & Ref. 11,12 & $13(0.6)$ & 2058 & 1.00 & $\chi^{2}=518.326 ; p<0.001$ \\
\hline 2001-2005 & Overall & $\begin{array}{l}\text { Ref. } 11,16,17,18,19 \text {, } \\
20,21,22,23,24,25 \\
26,27,28,29,30,31 \\
32,33\end{array}$ & $2168(5.4)$ & 39832 & $9.05(5.1-16.3)$ & - \\
\hline $2011-2015$ & Overall & $\begin{array}{l}\text { Ref. } 54,55,56,57,58, \\
59,60,61,62,63,64,65 \\
66,67\end{array}$ & $9594(7.3)$ & 131057 & $12.43(7.1-22.4)$ & - \\
\hline
\end{tabular}

*Year during which the field study was conducted

OR: odds ratio, $\mathrm{CI}$ : confidance interval

\section{Ethics}

Ethics Committee Approval: Information reported in this retrospective study was collected by references to published works.

\section{Authorship Contributions}

Concept: Züleyha Alper, Yeşim Uncu, İlker Ercan, Design: Züleyha Alper, İlker Ercan, Yeşim Uncu, Data Collection or Processing: Züleyha Alper, İlker Ercan, Analysis or Interpretation: İlker Ercan, Literature Search: Züleyha Alper, Yeşim Uncu, Writing: Züleyha Alper.

Financial Disclosure: The authors declared that this study received no financial support.

\section{References}

1. Itagi V. Patil R. Obesity in children and adolescents and its relationship with hypertension. Turkish J Med Sci 2011;41:259-266.

2. WHO. Fiscal policies for diet and the prevention of noncommunicable diseases. WHO Reg Off Eur 2015;36. http://www.who.int/ dietphysicalactivity/publications/ fiscal-policies-diet-prevention/en/.

3. Ng M. Fleming T. Robinson M. Thomson B. Graetz N. Margono C. Mullany EC. Biryukov S. Abbafati C. Abera SF. Abraham JP. AbuRmeileh NM. Achoki T. AlBuhairan FS. Alemu ZA. Alfonso R. Ali MK. Ali R. Guzman NA. Ammar W. Anwari P. Banerjee A. Barquera S. Basu S. Bennett DA. Bhutta Z. Blore J. Cabral N. Nonato IC. Chang JC. Chowdhury R. Courville KJ. Criqui MH. Cundiff DK. Dabhadkar KC. Dandona L. Davis A. Dayama A. Dharmaratne SD. Ding EL. Durrani AM. Esteghamati A. Farzadfar F. Fay DF. Feigin VL. Flaxman A. Forouzanfar MH. Goto A. Green MA. Gupta R. Hafezi-Nejad N. Hankey 
GJ. Harewood HC. Havmoeller R. Hay S. Hernandez L. Husseini A. Idrisov BT. Ikeda N. Islami F. Jahangir E. Jassal SK. Jee SH. Jeffreys M. Jonas JB. Kabagambe EK. Khalifa SE. Kengne AP. Khader YS. Khang YH. Kim D. Kimokoti RW. Kinge JM. Kokubo Y. Kosen S. Kwan G. Lai T. Leinsalu M. Li Y. Liang X. Liu S. Logroscino G. Lotufo PA. Lu Y. Ma J. Mainoo NK. Mensah GA. Merriman TR. Mokdad AH. Moschandreas J. Naghavi M. Naheed A. Nand D. Narayan KM. Nelson EL. Neuhouser ML. Nisar MI. Ohkubo T. Oti SO. Pedroza A. Prabhakaran D. Roy N. Sampson U. Seo H. Sepanlou SG. Shibuya K. Shiri R. Shiue. Singh GM. Singh JA. Skirbekk V. Stapelberg NJ. Sturua L. Sykes BL. Tobias M. Tran BX. Trasande L. Toyoshima H. van de Vijver S. Vasankari TJ. Veerman JL. Velasquez-Melendez G. Vlassov VV. Vollset SE. Vos T. Wang C93. Wang X94. Weiderpass E95. Werdecker A96. Wright JL97. Yang YC98. Yatsuya H99. Yoon J100. Yoon SJ. Zhao Y. Zhou M. Zhu S. Lopez AD. Murray CJ. Gakidou E.Global. regional. and national prevalence of overweight and obesity in children and adults during 1980-2013: A systematic analysis for the Global Burden of Disease Study 2013. Lancet 2014;384:766-781.

4. Sağlık Bakanlığı. Türkiye Beslenme ve Sağlık Araştırması 2010: Beslenme Durumu ve Alışkanlıklarının Değerlendirilmesi Sonuç Raporu.; 2014.

5. T.C. Sağlık Bakanlığı. Temel Sağlık Hizmetleri Genel Müdürlüğü. Türkiye'de okul çağı çocuklarında büyümenin izlenmesi projesi araştırma raporu. Ankara. 2011:1-121. http://beslenme.gov.tr/content/ files/yayinlar/kitaplar/diger_kitaplar/tocbi_kitap.pdf

6. Gümüş E. Satman I. Yetkin İ. Hatun Ş. Çakır B. Türkiye Diyabet Programı 1. 2015:1-66.

7. http://www.uludag.edu.tr/kutuphane/default/database

8. Neyzi O. Bundak R. Gökçay G. Günöz H. Furman A. Darendeliler F. Baş F. Reference Values for Weight. Height. Head Circumference. and Body Mass Index in Turkish Children. J Clin Res Pediatr Endocrinol 2015;7:280-293.

9. Kuczmarski RJ. Ogden CL. Grummer-Strawn LM. Flegal KM. Guo SS. Wei R. Mei Z. Curtin LR. Roche AF. Johnson CL. CDC growth charts: United States. Adv Data 2000;(314):1-27.

10. http://www.who.int/growthref/who2007_bmi_for_age/en/

11. Agirbasli M. Tanrikulu B. Arikan S. Izci E. Ozguven S. Besimoglu B. Ciliv G. Maradit-Kremers H. Trends in body mass index. blood pressure and parental smoking habits in middle socio-economic level Turkish adolescents. J Hum Hypertens 2008;22:12-17.

12. Agirbasli M. Cakir S. Ozme S. Ciliv G. Metabolic syndrome in Turkish children and adolescents. Metabolism 2006;55:1002-1006.

13. Ucar B. Kilic Z. Colak O. Oner S. Kalyoncu C. Coronary risk factors in Turkish schoolchildren: Randomized cross-sectional study. PED Pediatr Int 2000;42:259-267.

14. Soylu A. Kavukcu S. Turkmen M. Cabuk N. Duman M. Effect of socioeconomic status on the blood pressure in children living in a developing country. Pediatr Int 2000;42:37-42.

15. Kurdak H. Bozdemir N. Saatci E. Ozturk P. Ozcan S. Akpinar E. Self-perceived body weight status and weight-control behaviors of high school students in a southern city of Turkey. Coll Antropol 2010;34:1295-1302.

16. Ece A. Ceylan A. Gürkan F. Dikici B. Bilici M. Davutoglu M. et al. Diyarbakir ve Çevresi Okul Çocuklarinda Boy Kisaligi. Dusuk Agirlik ve Obezite Sikligi. Van Tip Derg 2004;11:128-136.

17. Saglam H. Tarim Ö. Prevalence and correlates of obesity in schoolchildren from the city of Bursa. Turkey. J Clin Res Pediatr Endocrinol 2008;1:80-88.

18. Sur H. Kolotourou M. Dimitriou M. Kocaoglu B. Keskin Y. Hayran O. Manios Y. Biochemical and behavioral indices related to BMI in schoolchildren in urban Turkey. Prev Med (Baltim) 2005;41:614-621.
19. Gundogdu Z. Relationship between BMI and blood pressure in girls and boys. Public Health Nutr 2008;11:1085-1088.

20. Aydin N. İrgil E. Akiş N. Pala K. Nilüfer Halk Sağlığı Eğitim Araştırma Bölgesinde Dört İlköğretim Okulundaki Öğrencilerin Sağllk Durumlarının Değerlendirilmesi. Uludag Univ Tip Fak Derg 2004;30:1-6.

21. Simsek F. Ulukol B. Berberoglu M. Gulnar SB. Adiyaman P. Ocal G. Ankara'da bir ilköğretim okulu ve lisede obezite sıklığ́. Ankara Üniversitesi Tıp Fakültesi Mecmuası 2005;58:163-166.

22. Turkkahraman D. Bircan I. Tosun O. Saka O. Prevalence and risk factors of obesity in school children in Antalya. Turkey. Saudi Med J 2006;27:1028-1033.

23. Süzek H. Arı Z. Uyanık BS. Muğla'da yaşayan 6-15 yaş okul çocuklarında kilo fazlalığ́ ve obezite prevalansı. Türk Biyokim Derg 2005;30:290295.

24. Nur N. Cetinkaya S. Yilmaz A. Ayvaz A. Bulut MO. Sumer H. Prevalence of hypertension among high school students in a middle anatolian province of Turkey. J Heal Popul Nutr 2008;26:88-94.

25. Bayat M. Erdem E. Barik O. Baser M. Tasci S. Blood pressure. height. weight and body mass index of primary school students in a low socioeconomic district in Turkey. Int Nurs Rev 2009;56:375-380.

26. Anamur Uguz M. Bodur S. Konya il merkezindeki ergenlik öncesi ve ergen çocuklarda aşırı ağırlık ve şişmanlık durumunun demografik özelliklerle ilişkisi. Genel Tıp Derg 2007;1 7:1-7.

27. Discigil G. Prevalence of hypertension and related factors in primary school students in Aydın. Turkiye Aile Hekim Derg 2008;12:70-74.

28. Dinc G. Saatli G. Baydur H. Ozcan C. Hypertension and overweight among Turkish adolescents in a city in Aegean region of Turkey: a strong relationship in a population with a relatively low prevalence of overweight. Anadolu Kardiyol Derg 2009;9:450-456.

29. Discigil G. Tekin N. Soylemez A. Obesity in Turkish children and adolescents: Prevalence and non-nutritional correlates in an urban sample. Child Care Health Dev 2009;35:153-158.

30. Ozturk A. Mazicioglu M. Poyrazoglu S. Cicek B. Gunay O. Kurtoglu $\mathrm{S}$. The relationship between sleep duration and obesity in Turkish children and adolescents. Acta Paediatr 2009;98:699-702.

31. Kara IH. Dikici B. Yel S. Ozdemir Ö. The prevalence of malnutrition and obesity in schoolchildren in the Southeast Anatolia Region of Turkey. Duzce Med J 2010;12:54-62.

32. Etiler N. Cizmecioglu FM. Hatun S. Hamzaoglu O. Nutritional status of students in Kocaeli. Turkey: A population-based study. Pediatr Int 2011;53:231-235.

33. Ozturk A. Akturk S. Ilköğretim öğrencilerinde obezite prevalansı ve ilişkili risk faktörleri. TAV Prev Med Bull 2011;10:53-60.

34. Ozmen D. Ozmen E. Ergin D. Cetinkaya AC. Sen N. Dundar PE. Taskin EO. The association of self-esteem. depression and body satisfaction with obesity among Turkish adolescents. BMC Public Health 2007;7:80.

35. Simsek E. Akpinar S. Bahcebasi T. Senses DA. Kocabay K. The prevalence of overweight and obese children aged 6-17 years in the West Black Sea region of Turkey. Int J Clin Pract 2008;62:1033-1038.

36. Ari Z. Süzek $H$. Muğla merkez köylerindeki bir grup ilköğretim okulu ögrencisinde serum lipid profili ve obezite taraması. Serum Lipid Profile and Obesity Scanning of A Group of Primary School Students in Central Villages of Mugla Province. ADÜ Tıp Fakültesi Derg 2008;9:11-16.

37. Akis N. Pala K. Meriç-Utku A. Seyithan B. Sarandöl E. Aytekin H. Hypertension in children (12-14 years)--a case-control study in Bursa. Turkey. Turk J Pediatr 2009;51:437-443.

38. Calisir H. Karacam Z. The prevalence of overweight and obesity in primary schoolchildren and its correlation with sociodemographic factors in Aydin. Turkey. Int J Nurs Pract 2011;17:166-173. 
39. Aslan Baran D. Bursa il merkezinde ilköğretim çağındaki çocuklarda hipertansiyon sıklığının ve risk faktörlerinin araştırılması. Ulusal Tez Merkezi 2008.

40. Borici S. Agaoglu NB. Baykan OA. Agirbasli M. Blood pressure and anthropometric measurements in Albanian versus Turkish children and adolescents. Acta Cardiol 2009;64:747-754.

41. Arı Yuca S. Yılmaz C. Cesur Y. Doğan M. Kaya A. Başaranoğlu M. Prevalence of Overweight and Obesity in Children and Adolescents in Eastern Turkey-Original Article. J Clin Res Pediatr Endocrinol 2010;2:159-163.

42. Kaya CA. Akman M. Unalan PC. Demir HP. Keskin S. Weight. diet and physical activity habits of Turkish adolescents living in a semi-urban area of Istanbul: gender differences. Obe Metab 2010;6:94-99.

43. Pirincci E. Durmus B. Gündogdu C. Acik Y. Prevalence and risk factors of overweight and obesity among urban school children in Elazig city. Eastern Turkey. 2007. Ann Hum Biol 2010;37:44-56.

44. Aksoydan E. Cakir N. Adölesanlarin beslenme alişkanliklari. fiziksel aktivite düzeyleri ve vücut kitle indekslerinin değerlendirilmesi. Gulhane Med J 2011;53:264-270.

45. Duzova A. Yalcinkaya F. Baskin E. Bakkaloglu A. Soylemezoglu O. Prevalence of hypertension and decreased glomerular filtration rate in obese children: results of a population-based field study. Nephrol Dial Transplant 2013;28(suppl 4):iv166-iv171.

46. Kesim S. Cicek B. Aral CA. Ozturk A. Mazicioglu MM. Kurtoglu S. Oral health. obesity status and nutritional habits in Turkish children and adolescents: An epidemiological study. Balkan Med J 2016;33:164-1 72.

47. Akcam M. Boyaci A. Pirgon O. Dundar B. Isparta ilindeki on okulda çocukluk çağ́1 şişmanlık sıklığı değiş̧iminin değerlendirilmesi. Turkish Arch Pediatr 2008;(1):152-155.

48. Akan H. Izbirak G. Tanriover O. Kaspar EÇ. Yıldız A. Tilev SM. Tektaş S. Vitrinel A. Ergenlerde prehipertansiyon ve hipertansiyon sikligi. Turk Aile Hek Derg 2010;14:115-123.

49. Akman M. Akan H. Izbirak G. Tanriöver Ö. Tilev SM. Yildiz A. Tektaş S. Vitrinel A. Hayran O. Eating patterns of Turkish adolescents: a crosssectional survey. Nutr J 2010;9:67.

50. Kayıran PG. Taymaz T. Kayıran SM. Memioğlu N. Taymaz B. Gürakan B. Türkiye'nin üç farklı bölgesinde ilköğretim okulu öğrencilerinde kilo fazlalığı . obezite ve boy kısalığı sıklığı. 2011;(1):13-18.

51. Albayrak B. Kutlu Y. The determination of blood pressure. anger expression and body mass index in adolescents in Turkey: a pilot study. Coll Antropol 2012;36:87-92.

52. Dündar C. Öz H. Obesity-Related Factors in Turkish School Children. Sci World J 2012;2012:1-5.

53. Onsuz FM. Demir F. Prevalence of hypertension and its association with obesity among school children aged 6-15 living in Sakarya province in Turkey. Turkish J Med Sci 2015;45:907-912.
54. Ercan S. Dallar YB. Onen S. Engiz O. Prevalence of obesity and associated risk factors among adolescents in Ankara. Turkey. J Clin Res Pediatr Endocrinol 2012;4:204-207.

55. Yorulmaz H. Perçin Paçal F. 16-18 Yaş Grubundaki Gençlerin Beslenme Aliskanliklarinin Ve Obezite Durumlarinin Incelenmesi. Turkiye Klin J Med Sci 2012;32:364-370.

56. Inanc B. 7-15 Years Of Age Group Children's Hypertension and Obesity. J Clin Anal Med 2013;4:116-119.

57. Cabar HD. Ozeren GS. Altay B. Nutritional habits and obesity: Primary school students in Sinop. the northernmost point of Turkey. J Exp Clin Med 2014;31:13-17.

58. Kaya M. Sayan A. Birinci M. Yildiz M. Turkmen K. The obesity prevalence among students between the ages of 5 and 19 in Kutahya. Turkish J Med Sci 2014;44:10-15.

59. Demirci H. Nuhoglu C. Ursavas IS. Isildak S. Basaran EO. Kilic MY Obesity and asymptomatic hypertension among children aged 6-13 years living in Bursa. Turkey. Fam Pract 2013;30:629-633.

60. Polat M. Yıkılkan H. Aypak C. Görpelioğlu S. The relationship between BMI and blood pressure in children aged 7-12 years in Ankara. Turkey. Public Health Nutr 2014;17:2419-2424.

61. Turhan E. Tözün M. Doğanay S. İzmir’E Bağlı Dokuz Ilçede Ilköğretim Birinci Sınıf Öğrencilerinde Obezite Sıklığı. J Clin Anal Med 2015;6:755759.

62. Sarı HY. Y1lmaz M. Serin E. Kısa SS. Yeşiltepe Ö. Tokem Y. Rowley H. Obesity and hypertension in adolescents and adults with intellectual disability. Acta Paul Enferm 2016;29:169-177.

63. Gokler ME. Bugrul N. Metintas S. Kalyoncu C. Adolescent obesity and associated cardiovascular risk factors of rural and urban life (Eskisehir. Turkey). Cent Eur J Public Health 2015;23:20-25.

64. Ozcebe H. Bosi TB. Yardim N. Ertuğrul Ç. Nermin Ç. Bekir K. Seçil Ö. Türkiye' de çocuklarda fazla kiloluluk ve şişmanlık prevalansları [Owerweight and obesity among children in Turkey]. TAF Prev Med Bull 2015;14:145-152.

65. Dastan I. Cetinkaya V. Delicen ME. The obesity and overweight prevalence among students between the ages of 7 and 18 in İzmir. Bakirkoy Tip Derg / Med J Bakirkoy 2014;10:139-146.

66. Cam H. Top F. A Study on the Prevalence of Prehypertension and Hypertension and its Association with Obesity in Adolescents [Adolesanlarda Prehipertansiyon ve Hipertansiyon Prevalansi ile Obezite Arasindaki Iliskinin Incelenmesi]. Med Sci | Int Med J 2015;4:2143.

67. Kecialan R. Kosif R. Examining Of The Relationship Between Waist To Height Ratio. The Dietary Habits And Body Mass Index (BMI) Of Students In A Vocational Health High School. HealthMED 2016;10:149161. 